\title{
What factors prevent young adults from showing up for their addiction treatment?
}

Anne Lene Årseth

Sykepleier og prosjektleder

Avdeling for rus- og avhengighetsbehandling, Sørlandet sykehus, Kristiansand

Erik Torjussen

Brukerrepresentant

A-larm

Berit Johannessen

Førsteamanuensis

Institutt for helse- og sykepleievitenskap, Fakultet for helse- og idrettsvitenskap,

Universitetet i Agder

Interdisciplinary specialised addiction treatment

Transitions

Patient experiences

Treatment dropout

Sykepleien Forskning 201914 (76440) (e-76440)

\section{Summary}

Background: Between 10 and 60 per cent of those who embark on an interdisciplinary specialised addiction treatment programme drop out of the programme before completion. The transition from one place of treatment to another is frequently found to be a vulnerable period, and we know from clinical experience that there is a dropout risk when patients are referred from one institution to another. 
A treatment dropout project at the department for substance abuse and addiction treatment at the Hospital for Southern Norway found that 48 per cent of patients under 30 years of age dropped out of the programme during the period of transition from one place of treatment to another (3). The high dropout rate prompted a need to obtain more knowledge from the patients about why they failed to show up for treatment. Few existing studies have looked into the perceptions and experiences of this patient group in connection with treatment dropout.

Objective: The study's objective was to gain further insight into what factors prevent young adult patients from showing up for addiction treatment in private in-patient institutions within the interdisciplinary specialised addiction treatment service.

Method: The study has a qualitative design. We conducted semi-structured life story interviews with five informants who had failed to show up for addiction treatment in a private institution. We analysed the data by means of systematic text condensation.

Results: The results highlight a sense of inadequate involvement, uncertainty, anxiety and dwindling motivation during the waiting period and a feeling of being pressurised into applying for and accepting the treatment offer.

Conclusion: The findings suggest that there is a need within the interdisciplinary specialised addiction treatment service to increase the knowledge about service user involvement and to strengthen the focus on individualised treatment, relationships and close follow-up during transition periods. There is a need for further research that sheds light on the service users' own perceptions and experiences in connection with the treatment they receive within the interdisciplinary specialised addiction treatment service.

Between 10 and 60 per cent of those who embark on an interdisciplinary specialised addiction treatment programme drop out of the programme before completion (1). Among these dropouts there is greater probability of rehospitalisation, poorer physical and mental health, and relapses (2). In order to increase the completion rate, the Norwegian Ministry of Health and Care Services granted project funding in 2014 to each of the regional health authorities. 
The department for substance abuse and addiction treatment at the Hospital for Southern Norway (SSHF) was awarded funding for a treatment dropout project that, among other things, examined the transition period between receiving treatment in the hospital department and admission to a private in-patient institution. This part project defined 'treatment dropout' as the discontinuation of treatment before completion, the turning down of an offer of a place, and the failure to turn up at the start of the treatment programme.

The department for substance abuse and addiction treatment offers a range of different treatments, and most patients who continue on a long-term therapy programme are referred to a private in-patient institution in the voluntary sector. The various private institutions employ different methodologies and provide treatment programmes of between six and twelve months' duration. In 2013, the average waiting period between the offer of a place and treatment start-up was 72 days (3).

\section{Different patient pathways}

Patients follow different pathways before admission to a private institution. They may be referred by their GP, the local authority's addiction service, the Norwegian Labour and Welfare Administration or the specialist health service. When their application is submitted to the assessment team at the department for substance abuse and addiction treatment, the team decide whether the patient is entitled to treatment, and what level of treatment is appropriate. The application is then forwarded for assessment by the private institution in question. Patients are free to choose among the options available at the level of treatment for which they receive an offer.

\section{$\equiv$ «The transition from one place of treatment to another may put the patient in a vulnerable situation.»}

The transition from one place of treatment to another may put the patient in a vulnerable situation. The part project conducted at the department for substance abuse and addiction treatment found that 48 per cent of patients dropped out during the period of transition from one institution to another (3). The high dropout rate prompted a need to obtain more knowledge from patients about the factors that prevented them from turning up. 


\section{Earlier research on the topic}

Government guidelines emphasise the importance of allowing service user experiences to play a bigger part in the development of good and efficient services (4). User involvement and a good alliance between the patient and the therapist are considered keys to preventing treatment dropout (5). Nonetheless, few studies have investigated the patients' own perceptions and experiences associated with dropping out of treatment programmes.

A recent review article showed that, with the exception of increased vulnerability with lower age, no patient-related factors could be said to unequivocally explain the programme dropout rate. Only six of the 122 studies had investigated factors relating to the therapist. These studies showed that a close alliance between the therapist and the patient may lead to lower treatment dropout rates.

The review article authored by Brorson et al. asks for more research into treatment processes, for example patient satisfaction levels (1).

We have found no studies that investigate the failure to turn up for treatment seen from the patients' perspective. Studies that have investigated the reasons why patients discontinue their treatment before completion, cite factors such as dissatisfaction with the treatment programme and a lack of flexibility in the planning phase $(6,7)$.

Studies that have investigated patient perceptions of treatment received, refer to various needs and opinions, but involvement, therapeutic alliances and being taken seriously and being respected were recurring themes (8-10).

\section{The study's objective}

The study's objective was to gain further insight into what factors prevent young adult patients from showing up for addiction treatment in a private in-patient institution.

\section{Method}


The study has a qualitative design. Since we wanted a deeper insight into the stories of individual service users, we made use of semi-structured life story interviews, characterised by questions that are neither completely open-ended nor completely closed-ended (11). We drew up an interview guide that focused on topics we wanted answers to: the informants' experiences in the process leading up to hospitalisation, their positive and negative experiences and their reasons for failing to turn up.

\section{Sample}

Our informants had to have capacity to consent in order to be included in the sample; also, they could not be too affected by drugs to complete the interview, nor could they be admitted for treatment or imprisoned.

In order to identify suitable informants, we conducted searches in the hospital's patient records. Out of 20 people, six met the criteria and the first author contacted them by phone. We managed to contact five informants, all of whom wanted to be interviewed. However, two of the informants did not turn up, and after a further check of patient records for potential informants the first author contacted two people who had been admitted for in-patient treatment. Both wished to take part in the study, and both turned up for an interview.

The sample included three males and two females between the ages of 18 and 30. Their respective treatment pathways had been different until they applied for treatment at one of four private institutions in 2013. All had a long track record of receiving help with their addiction problem, and all had previous experience of treatment in a private institution.

At the time of their referral to a private institution in 2013, they were all receiving some form of assistance from agencies such as the specialist health service, the Norwegian Labour and Welfare Administration, the local authorities, their GP or the child welfare service, and one of these agencies had applied for them to be admitted. Three of the informants were drug dependent at the time of referral, one had stayed off drugs for a few weeks, while one had been clean for a longer period of time.

At the time of the interview, two of the informants were receiving the treatment they wanted, one was receiving stable drug-assisted treatment, while two had stayed clean for months. 
The informants conveyed that the opportunity to pass on their story was important to them, in order to help other people experience a better treatment process than they had done.

\section{Conducting the interviews}

The first and second authors conducted the interviews. They were conducted at different premises according to the wishes of the informants and they lasted for 50 to 80 minutes. Several informants mentioned that the presence of a user representative during the interview was a positive aspect. We made audio recordings that were later transcribed by ourselves; the material made up a total of 115 pages of text. The text was then read and analysed by all authors.

\section{Analysis}

The first author conducted the analysis by means of systematic text condensation according to Malterud's (12) four-step model. We started by reading through the interviews from what Malterud (12) calls a bird's eye perspective in order to form an impression of relevant themes. We then re-read the interviews, coded and sorted them by putting text fragments together as we found appropriate under each theme heading. All text that did not fit into a category was put to one side.

We went on to re-write the text fragments in less verbatim language, combining fragments with similar content. We retained quotes that might serve to complement the content. Afterwards, each theme was again reviewed, and each text fragment re-assembled under each theme. In the end, all authors reviewed all interviews again to see if the descriptions matched what the informants had said. The analysis generated three main themes.

\section{Ethical aspects}

We submitted the study to the Regional Committees for Medical and Health Research Ethics (REC) and it was concluded that project authorisation was not required. The study has been approved by the Norwegian Centre for Research Data (NSD).

The informants received verbal and written information about the study. Confidentiality was maintained by storing all data on a password protected memory stick placed in locked storage. Only the authors had access to the memory stick. All data were anonymised to ensure that no individuals could be identified. 
The informants signed a consent declaration and were able to withdraw from the study at any time without giving a reason, and without consequence to any treatment they may have been receiving. Nobody chose to withdraw. All informants had access to someone to talk to in the aftermath of the study.

\section{Results}

The results show that the informants felt there was inadequate service user involvement, they felt anxious and upset, and their motivation was dwindling during the waiting period. There was also a sense of being pressurised into accepting the treatment offer, and this stopped them from turning up for treatment.

\section{Insufficient involvement}

All the informants had envisioned what kind of help they needed to free themselves of their addiction. Four of them had conveyed their needs and wishes before their application for treatment had been submitted. However, they had all found that their application had been for a different programme or institution than the one they wanted:

'I really wanted to be admitted to one specific institution, I suppose, but then the support services applied to have me admitted elsewhere. They felt that's where I ought to go, so I ended up not [...] I turned down the offer, you see.'

The informants had been given a variety of reasons why their wishes had not been granted: the institution's waiting time was too long, they were not ready for that particular type of treatment or follow-up, they did not fulfil the criteria, or the help they wished for, did not exist.

\section{Neither heard nor seen}

The fact that they were not granted the assistance they wanted, meant that they felt their needs were neither listened to nor believed. They were left with a sense that the treatment they were granted was insufficiently adjusted to the individual:

'I think they're doing what their textbook says is the right thing to do, sort of. They probably did what they thought was right based on how they were used to doing things, but in my opinion that's not necessarily right, at least not in our case.' 
According to four of the informants, a recurring theme throughout their treatment pathway was that they had not been listened to nor taken notice of. One of them complained as follows:

'I have heard several [...] It's really that they're not listened to when they say something, and actually, those who are honest about what they hear and see; of course, there are those who try it on, but most of the people who admit themselves, they do so because they want to try, but when their voices aren't being listened to, then things aren't that easy.'

\section{Distrust on the part of the support system}

Several informants had found that the support system had little confidence in their ability to achieve what they wanted to achieve. One of them described the way she sensed this distrust:

'[...] and again, you need to try to trust people and support them, rather than like "but what if this and that happens". Yeah, sure, that sort of thing is quite stressful.'

One of the informants, who was pregnant and on drugs, encountered an exaggerated trust in her own ability to stop taking drugs of her own accord. For her, it would have been important that the treatment service realised she was lying about managing by herself.

\section{Angry and desperate}

Four of the informants described how angry they felt when they were not listened to or taken seriously. One of the informants, who had been clear about what help he needed, described it in these terms:

'What I remember is the feeling I was left with when I was reaching out for help, and then I didn't get any help. I remember getting bloody pissed off. Then there's no point, I thought. I might as well continue the way I am. I'm not getting any help even if I'm asking for it.'

The fact that he was neither heard nor taken seriously, meant he felt there was no point in asking for more help. 
Informant

\section{Uncertainty, anxiety and dwindling motivation}

The informants experienced uncertainty, anxiety and dwindling motivation in the time leading up to their admission. For many, the waiting period was too long and they felt they were not receiving sufficient follow-up. One of them had stayed off drugs for a long time and was uncertain how long he would be able to keep it up:

'The problem was really that all my motivation went down the pan, and then I would have to mobilise all over again [...] I was like really annoyed that I had to wait for such a long time, 'cause I didn't know how long I would manage to stay clean before I was to be admitted.'

In addition, he felt he was receiving little follow-up from the institution he was being admitted to. All things combined, this meant he lost his motivation for treatment.

\section{Loss of confidence}

Another informant became anxious and lost her confidence in her own ability to go through with the treatment:

'I panicked, really. I think I became fearful of giving up the dope, of addressing some of the feelings I knew I had to address [...], 'cause I really believed that perhaps I wouldn't be up to it. So I lost my confidence.'

The informants also felt they were receiving insufficient information during the waiting period. One of them said:

'In fact, it would have been really good if they told you a bit about the place you're going to, and what the programme is and a little about how things work, 'cause I've never known any of that stuff whenever I've gone somewhere.'

Another informant had received some information but didn't feel receptive. A lack of information had a negative impact on their motivation.

\section{Feeling pressurised to accept the offer of a place}


Four of the informants had felt pressurised into accepting when they were offered a place in the institution that had been suggested by the support service, even if this was not the one that they themselves had wanted. The reason given by several informants was that they had not felt ready for this type of treatment.

One of the informants talked about how in 2013 and on several other occasions she had been pressurised into accepting treatment in an institution. She had accepted so that she would not lose custody of her children:

'[...] maybe I wasn't receptive the other times I was receiving treatment; I was doing it just because I felt I had to, because I had been given an ultimatum - they would take away my kids if I didn't.'

The pressure applied by the care system had made her make a half-hearted attempt at ridding herself of her addiction.

\section{A sense of being pressurised by the Norwegian Labour and Welfare Administration}

Another informant talked of financial pressure, and how he had felt that the Norwegian Labour and Welfare Administration had the upper hand:

'The Social had me in a hold so to speak, they could stop the money coming in if I didn't stick to the plan, and I was totally dependent on the cash, I never managed to hang on to a job or anything, to get an income. So I had to do what I had to do, in a way, to get the money.'

Four of the informants had declined an offer of a place. They had chosen to go their own way in their effort to free themselves of their substance addiction, although they felt that they were receiving little support from the support system, and that it was a struggle to find approval for their own wishes.

\section{Discussion}

The study's objective was to gain insight into the factors that prevent young adult patients from turning up for addiction treatment in private in-patient institutions. The results show that they experienced inadequate service user involvement, uncertainty, anxiety and dwindling motivation while waiting for admission, and that they felt pressurised into accepting an offer of treatment. 


\section{The service user has a right to be involved}

The findings show that the informants felt their opportunity for user involvement was inadequate. On an individual level, service user involvement means that patients are kept involved by being asked to choose between safe and available treatment and examination options, and that their opinions must carry considerable weight. This involvement is an entitlement enshrined in law and forms a part of the obligation to provide safe and appropriate services (13).

The informants' experiences appear to be at odds with the requirement for service user involvement, which is a finding reflected in other studies (8-10). There are several challenges ahead before the potential for service user involvement has been fully exhausted (14). The user involvement requirement represents a change to the notion that patients should adjust to the services rather than the other way around (15).

Moreover, the expert role assumed by healthcare personnel must change. Staff object to involving substance abuse patients with their own addiction treatment and argue that the substance abusers' 'chaotic' lifestyle, and the addiction itself, will limit the individual's capacity to participate (16).

However, studies show positive results from involving service users with treatment provided by the interdisciplinary specialised addiction services: patients stay on their treatment programmes for longer, the level of heroin use is reduced, there is less crime, and the patients' empowerment increases (16-18).

\section{Felt they were not taken seriously}

Several informants talked of anger and despair when they felt that their wishes were not listened to, and that they were not taken seriously. The few studies that have examined what patients consider to be the key to a good treatment offer, show that a high rate of satisfaction is associated with staff taking patients seriously (8-10).

Being taken seriously, and being respected, is considered to be particularly important for people who suffer from substance addictions because many have experienced disdain and a lack of respect (8). 
The informants felt that they were pressurised into accepting an offer of treatment they did not want. Patient empowerment prevents a sense of powerlessness in patients who feel they have little control of their own lives in their encounters with the support system (15).

\section{三 «The informants felt that they were pressurised into accepting an offer of treatment they did not want.»}

A recent publication features the stories of 14 individuals and their struggle to rid themselves of their drug addiction. Their stories support the notion that for the support system to help people free themselves of their addictions, the most effective approach is to allow the individual's preferences, values and contexts to form the starting point (19).

A good alliance is characterised by the therapist and patient working as a team in full agreement about the goals and targets, and about how they should be working together. Several studies show that the quality of the relationship between the therapist and the patient is one of the best treatment outcome indicators $(1,20,21)$.

\section{Essential to provide motivation and prevent treatment drop-out}

The informants referred to minimal follow-up and dwindling motivation while waiting to be admitted. Motivation is key to all change processes. Fluctuating levels of motivation are to be expected; ambivalence and resistance to change form part of the process that leads to freedom from addiction (22). Becoming drug free is a change process that takes years to achieve, and that needs constant attention (20).

Other studies have also found that patients drop out of treatment programmes because they are not ready (23). However, dropping out of a programme does not necessarily mean an end to all treatment (24). Good treatment may involve providing patients with follow-up and support as they go through their processes, in a way that is adjusted to the patient's pace, needs and targets, and which takes account of their resources and dreams (19).

\section{Methodology consideration}


The study includes a small number of informants, and all of them were recruited because they had received treatment at the same hospital and failed to turn up for treatment at a private institution in 2013. The study cannot be used for generalisation purposes but must be seen as a contribution to gaining further knowledge about the factors that prevent young patients from turning up for treatment.

The study's strength is that we used the same interview guide for all informants. The guide's open-ended questions gave informants an opportunity to talk freely. Their experiences and perceptions varied. All of them were keen and had formed many thoughts and opinions on the topic. However, the experiences featured in the informants' accounts were not recent, which may have affected the results.

It was also a strength that a user representative was involved with the design and implementation of the study, to ensure that both the 'professional view' and the 'service user view' were represented throughout the process. The authors' preconceptions will inevitably influence the interviews and the analysis process, and we sought to achieve reflexivity since all authors are working within the field.

The informants said that the presence of a service user representative instilled a sense of safety in them. This may have caused the informants to give different answers than if the first author had conducted the interviews on her own.

\section{Conclusion}

The factors that prevented the informants from turning up for treatment at the private institution, were a sense of inadequate user involvement, dwindling motivation and being pressurised to accept a treatment they did not want.

The study shows that there is an increased need to implement service user involvement and to strengthen the focus on individualised treatment. It also shows that a good relationship between the therapist and the service user is important, as is close follow-up during transition periods. There is a need for further research to shed light on the service users' own experiences and perceptions of treatment they receive within the interdisciplinary specialised addiction treatment service. 


\section{References}

1. Brorson H, Arnevik EA, Rand-Hendriksen K, Duckert

F. Drop-out from addiction treatment: a systematic review of risk factors. Clin Psychol Rev. 2013;33(8):1010-24.

2. Stark MJ. Dropping out of substance abuse treatment: A clinically oriented review. Clinical Psychology Review. 1992;12(1):93-116.

3. Gallefoss L, Årseth AL. Drop-out prosjektet. Delrapport 2. Pasientforløp og drop-out i overgang fra Avd. for rus- og avhengighetsbehandling (ARA) Sørlandet Sykehus $\mathrm{HF}$ til videre behandling i private døgninstitusjoner. Kristiansand: Sørlandet sykehus HF, Avdeling for rus- og avhengighetsbehandling; 2016.

4. $\quad$ St.prp. nr. 1 (2007-2008). Oslo: Helse- og omsorgsdepartementet; 2008. Available at: https://www.regjeringen.no/no/dokumenter/stprp-nr-12007-2008-/id483671/sec1 (downloaded 08.01.2019).

5. Helsedirektoratet. Nasjonal faglig retningslinje for behandling og rehabilitering av rusmiddelproblemer og avhengighet. Oslo; 2016. Available at: https://helsedirektoratet.no/retningslinjer/behandling-ogrehabilitering-av-rusmiddelproblemer-ogavhengighet (downloaded 02.11.2015).

6. Ball SA, Carroll KM, Canning-Ball M, Rounsaville BJ. Reasons for dropout from drug abuse treatment: Symptoms, personality, and motivation. Addictive Behaviors. 2006;31:320-30.

7. Laudet AB, Stanick V, Sands B. What could the program have done differently? A qualitative examination of reasons for leaving outpatient treatment. Journal of Substance Abuse Treatment. 2009;37:182-190.

8. Dahle KA, Iversen HH. Hva er viktig for pasienter innen rusbehandling? Notat fra Kunnskapssenteret. Oslo: Nasjonalt kunnskapssenter for helsetjenesten; 2011.

9. Nordfjærn T, Rundmo T, Hole R. Treatment and recovery as perceived by patients with substance addiction. Journal of Psychiatric and Mental Health Nursing. 2009;17(1):46-64. 
10. Hackman A, Brown C, Yang Y, Goldberg R, Kreyenbuhl J, Lucksted A, et al. Consumer satisfaction with inpatient psychiatric treatment among persons with severe mental illness. Community Mental Health Journal. 2007;43:551-64.

11. Kvale S, Brinkmann S. Det kvalitative

forskningsintervju. Oslo: Gyldendal Akademisk; 2010.

12. Malterud K. Kvalitative metoder i medisinsk forskning. En innføring. Oslo: Universitetsforlaget; 2003.

13. Helsedirektoratet. Veileder om rehabilitering, habilitering, individuell plan og koordinator. Oslo; 2015. Available at: https://helsedirektoratet.no/retningslinjer/rehabiliteringhabilitering-individuell-plan-og-koordinator (downloaded o8.01.2019).

14. Torjussen E, Harwiss HL, Havenes IA.

Brukermedvirkning i TSB - en myte? : en nasjonal kartlegging av brukermedvirkning i Tverrfaglig spesialisert behandling av ruslidelser (TSB). Oslo: Oslo universitetssykehus; 2014:1. Available at: https://oslo-

universitetssykehus.no/seksjon/nasjonal-kompetansetjenestefor-tverrfaglig-spesialisert-rusbehandlingtsb/Documents/SkriftserieNrENTilNett.pdf (downloaded 25.03.2019)

15. Dahl T. Brukeren som veileder. Ambulant brukerstyrt tilnærming. Oslo: Gyldendal Akademisk; 2011.

16. Fischer J, Neale J. Involving drug users in treatment decisions: an exploration of potential problems. Drugs Educ. Prev. Policy. 2008;15(2):161-75.

17. Nabitz U, van der Brink W, Walburg J. A quality framework for addiction treatment programs. Addict. Behav. 2005;30:1254-60.

18. Ning AM. Games of truth: rethinking conformity and resistance in narratives and heroin recovery. Med. Anthropol. 2005;24(4):349-82.

19. Landheim A, Wiig FL, Brendbekken M, Brodahl M. Biong S. Et bedre liv. Historier, erfaringer og forskning om recovery ved rusmiddelmisbruk og psykiske problemer. Oslo: Gyldendal Akademisk; 2016. 
20. Meier PS, Donmall MC, McElduff P, Barrowclough C, Heller RF. The role of the early therapeutic alliance in predicting drug treatment dropout. Drug and Alcohol Dependence. 2006;83(1):57-64.

21. Miller MR, Moyers TB. The forest and the trees: Relational and specific factors in addiction treatment. Addiction. 2014;110:401-13.

22. Biong S, Ytrehus S. Helsehjelp til personer med rusproblemer. Oslo: Akribe; 2012.

23. Palmer RS, Murphy MK, Piselli A, Bali SA. Substance abuse treatment drop-out from client and clinical perspectives. Substance Use Misuse. 2013;44(7):1021-38.

24. Nordheim K, Walderhaug E, Alstadius S, Kern-Godal A, Arnevik E, Duckert F. Young adults' reasons for dropout from residential substance use disorder treatment. Qual Soc Work. 2018;17(1):24-4O. DOI: 10.1177/1473325016654559. 